\title{
Three point bending flexural strength of cement treated tropical marine soil reinforced by lime treated natural fiber
}

\begin{abstract}
Marine soil in the Selangor State of Malaysia was characterized with respect to its engineering properties as pavement layer in road constructions. Samples were collected from North Klang area in Selangor, Malaysia and subjected to physico-chemical, mineralogical and geotechnical analyses. Quick lime or calcium oxide $(\mathrm{CaO})$ treated coconut fibers were introduced to soil cement mixture to enhance the flexural strength of tropical marine soil. Three point bending tests were carried out on treated samples after 7, 14 and 28 days respectively. The tests results showed improvements in the flexural performance of the mixture as it could be seen by the increase in the flexural strength, Young's modulus and the toughness index especially when the treated fibers were incorporated into the mixture. It was found that, the bond strength and interaction between treated fibers and soil was the dominant mechanism controlling the reinforcement benefit. It can be concluded that, the application of the $\mathrm{CaO}$ treated coconut fiber reinforced cement treated marine clay from Peninsular Malaysia is useful both in strength and ductility as pavement layer in road constructions.
\end{abstract}

Keyword: Three point bending; Flexural behaviour; Coconut fiber; Load deflection; Tropical marine clay; Cement treated clay 